University of South Florida

DIGITAL COMMONS

Digital Commons @ University of

@ UNIVERSITY OF SOUTH FLORIDA

South Florida

$5-1-2011$

\title{
Combination of Conjugated Linoleic Acid with Fish Oil Prevents Age-Associated Bone Marrow Adiposity in C57BI/6J Mice
}

\author{
Ganesh V. Halade \\ University of Texas Health Science Center at San Antonio, ghalade@usf.edu \\ Md M. Rahman \\ University of Texas Health Science Center at San Antonio \\ Paul J. Williams \\ University of Texas Health Science Center at San Antonio \\ Gabriel Fernandes \\ University of Texas Health Science Center at San Antonio
}

Follow this and additional works at: https://digitalcommons.usf.edu/intmed_facpub

\section{Scholar Commons Citation \\ Halade, Ganesh V.; Rahman, Md M.; Williams, Paul J.; and Fernandes, Gabriel, "Combination of Conjugated Linoleic Acid with Fish Oil Prevents Age-Associated Bone Marrow Adiposity in C57BI/6J Mice" (2011). Internal Medicine Faculty Publications. 69. \\ https://digitalcommons.usf.edu/intmed_facpub/69}

This Article is brought to you for free and open access by the Internal Medicine at Digital Commons @ University of South Florida. It has been accepted for inclusion in Internal Medicine Faculty Publications by an authorized administrator of Digital Commons @ University of South Florida. For more information, please contact digitalcommons@usf.edu. 


\title{
Combination of conjugated linoleic acid with fish oil prevents age-associated bone marrow adiposity in $\mathrm{C} 57 \mathrm{BI} / 6 \mathrm{~J}$ mice
}

\author{
Ganesh V Halade ${ }^{1}$, Md M Rahman ${ }^{1}$, Paul J Williams, and Gabriel Fernandes \\ Division of Clinical Immunology and Rheumatology, Department of Medicine, University of Texas \\ Health Science Center at San Antonio, 7703 Floyd Curl Drive, Texas 78229-3900, USA.
}

\begin{abstract}
The inverse relationship between fat in bone marrow and bone mass in the skeleton of aging subjects is well-known. However, there is no precise therapy for the treatment of bone marrow adiposity. We investigated the ability of conjugated linoleic acid (CLA) and fish oil (FO), alone or in combination, to modulate bone loss using 12 months old C57B1/6J mice fed $10 \%$ corn oil (CO) diet as control or supplemented with $0.5 \%$ CLA or $5 \% \mathrm{FO}$ or $0.5 \%$ CLA+5\% FO for 6 months. We found, CLA fed mice exhibited reduced body weight, body fat mass (BFM), and enhanced hind leg lean mass (HLLM) and bone mineral density (BMD) in different regions measured by DXA; however, associated with fatty liver and increased insulin resistance; whereas, FO fed mice exhibited enhanced BMD, improved insulin sensitivity, with no changes in BFM and HLLM. Interestingly, CLA+FO fed mice exhibited reduced body weight, $\mathrm{BFM}, \mathrm{PPAR}_{\gamma}$ and cathepsin $\mathrm{K}$ expression in bone marrow with enhanced BMD and HLLM. Moreover, CLA+FO supplementation reduced liver hypertrophy and improved insulin sensitivity with remarkable attenuation of bone marrow adiposity, inflammation and oxidative stress in aging mice. Therefore, CLA with FO combination might be a novel dietary supplement to reduce fat mass and improve BMD.
\end{abstract}

\section{Keywords}

Conjugated linoleic acid; bone adiposity; fat mass; fish oil; obesity

\section{Introduction}

\begin{abstract}
An enhanced adipogenesis in the bone marrow (BM) is inversely correlated to trabecular bone volume during aging and in patients with osteoporosis (1). Osteoporosis is a major public health concern characterized by excessive skeletal fragility in the aging population. The direct cost associated with obesity in the United States is $\sim \$ 100$ billion and for osteoporosis, it has risen rapidly and reached $\sim 17.5$ billion dollars per year (2). Bone tissue undergoes remodeling throughout life, balancing between bone resorption and bone formation. Imbalances of bone remodeling can result in gross perturbations in skeletal
\end{abstract}

\footnotetext{
(C) 2010 Elsevier Inc. All rights reserved.

Corresponding author Gabriel Fernandes Address: Division of Clinical Immunology and Rheumatology, Department of Medicine, University of Texas Health Science Center at San Antonio, 7703 Floyd Curl Drive, Texas 78229-3900, USA. Phone: 001-210-567-4663, Fax: 001-210-567-4592 fernandes@uthscsa.edu.

1 These two authors contributed equally

Publisher's Disclaimer: This is a PDF file of an unedited manuscript that has been accepted for publication. As a service to our customers we are providing this early version of the manuscript. The manuscript will undergo copyediting, typesetting, and review of the resulting proof before it is published in its final citable form. Please note that during the production process errors may be discovered which could affect the content, and all legal disclaimers that apply to the journal pertain.
} 
structure and function, and potentially to morbidity and shortening of lifespan (3). Currently there is no precise therapy to treat age-associated BM adiposity. Recently, there is an extensive interest in the potential health benefits of dietary supplementation with conjugated linoleic acid (CLA), including anti-carcinogenic and anti-tumorogenic effects (4), reduction in the risk of atherosclerosis, hypertension, and diabetes, improvement in food efficiency, promotion of energy metabolism, anti-osteoporotic and positive effect on immune function (5). On the other hand, the beneficial effect of FO has been demonstrated in several human diseases, including cardiovascular diseases (6), autoimmune inflammatory diseases, rheumatoid arthritis, inflammatory bowel disease, osteoporosis $(7,8)$, sepsis, vascular compliance, blood pressure (9), diabetes (10) etc. In view of its beneficial effects, the FO formulation OMACOR ${ }^{\circledR}$ (Currently marketed as LOVAZA ${ }^{\circledR}$, by GSK Inc. USA) has been approved by the FDA as an adjunct to diet in patients with high triglycerides. Similarly, CLA has achieved the Generally Recognized As Safe (GRAS) status by the FDA for its use in certain foods and beverages (11).

We and others have shown that CLA profoundly reduces body fat mass and is popularly used as a weight loss management strategy $(5,12)$. We have also reported that CLA is antiosteoclastogenic and is able to prevent age-associated bone loss in mice (13). However, CLA has been shown to exhibit some adverse effects (14) including reduction in insulin sensitivity in subjects with type 2 diabetes (15) and augmentation of the pre-existing insulin resistance $(16,17)$. Additionally, long-term studies in rodents have demonstrated a lipodystrophic effect of CLA (18) associated with decreases plasma adiponectin and leptin levels and increased insulin resistance (19). There are paradoxical findings that CLA causes liver enlargement (20) accompanied by increase in tissue lipid content in mice (14), whereas in obese insulin-resistant rats, it reduced the hepatic steatosis, improved liver function, and favorably modified lipid metabolism (21). On the other hand, FO has been shown to have beneficial effects on glucose and lipid metabolism in rodent studies, improve insulin sensitivity $(22,23)$, reduce triglyceride (24) and to improve bone mineral density (BMD) in ovariectomized mice (7). Thus, although CLA supplementation reduces body fat and osteoporotic bone loss, it is associated with hepatomegaly and insulin resistance, whereas FO is known to reduce triglycerides (TGs), improve insulin sensitivity, and enhance BMD. Therefore, we speculate that the combining CLA with FO could be an excellent strategy in the management of fat mass reduction and osteoporotic bone loss, circumventing the CLAinduced hepatomegaly and insulin resistance. In the present study, aging $\mathrm{C} 57 \mathrm{Bl} / 6 \mathrm{~J}$ mice were fed American Institute of Nutrition (AIN) 93 diet, containing 10\% corn oil (CO) as a dietary fat source, which promotes osteoporosis and obesity (25), glucose intolerance and insulin resistance thus representing a useful model for studying the early stages in the development of obesity $(25,26)$ and age-related bone loss $(25,27)$. The combined supplementation of CLA and FO showed reduced fat mass, reduced BM adiposity, improved hind leg lean mass (HLLM), improved BMD, along with no hepatomegaly and insulin resistance in $\mathrm{C} 57 \mathrm{~B} 1 / 6 \mathrm{~J}$ aging mice.

\section{Research Design and Methods}

\subsection{Animals}

Eleven month-old female C57B1/6J mice, weighing 24-26 g were purchased from Jackson Laboratories (Bar Harbor, Maine 04609 USA) and provided free access to water and standard chow AIN93G, which is the growth diet recommended by AIN for acclimatization for a period of one month. At twelve months, weight matched animals were divided into four groups containing 10 in each. Subsequently, the animals were housed in a standard controlled animal care facility in cages (5 mice/cage) and fed a diet containing CO, FO, CLA and combination of CLA and FO ad libitum for 6 months. The animals were maintained in temperature controlled room $\left(22-25^{\circ} \mathrm{C}, 45 \%\right.$ humidity $)$ on a 12 :12-h dark- 
light cycle. NIH guidelines were strictly followed, and all the studies were approved by the Institutional Laboratory Animal Care and Use Committee of the University of Texas Health Science Center, San Antonio, TX. Body weight was measured weekly.

\subsection{Diet preparation}

The 4 different experimental diets (Table 1) were prepared using AIN93G, supplemented with $\mathrm{CO}, \mathrm{FO}$, and CLA as follows,

a. Corn oil (CO) diet: supplemented with $10 \%$ corn oil,

b. FO diet: Supplemented with 5\% FO ((eicosapentaenoic acid (EPA)/ docosahexaenoic acid $(\mathrm{DHA})=30 / 20)$ ) with $5 \% \mathrm{CO}$,

c. CLA diet: Supplemented with $0.5 \%$ Clarinol-80 $80^{\mathrm{TM}}$ (containing 50:50 of cis 9 trans 11 CLA and trans 10 cis 12 CLA) in 9.5\% CO (CLA),

d. CLA+FO diet: Supplemented with $0.5 \%$ CLA in $4.5 \% \mathrm{CO}$ with $5 \% \mathrm{FO}$ (CLA+FO).

The Clarinol-80 $80^{\mathrm{TM}}$ was supplied by Lipid Nutrition, Channahon, IL, USA. FO (EPA/ DHA $=30 / 20$ ) was obtained from Ocean Nutrition, Canada. The mice were provided with fresh food everyday between 1.00-2.00 PM. Diets were prepared each week, purged with nitrogen, and frozen in daily portions in sealed polyethylene bags to minimize the oxidation of fatty acids. The composition of semi-purified diets is presented in Table 1.

\subsection{Measurement of BMD, total body fat mass and hind leg lean mass measured by DXA}

Region specific BMD, total body fat mass (BFM), and hind leg lean mass (HLLM) were measured by DXA before start of the AIN93 diet and after 6 months on the diets, and data were analyzed using Lunar PIXImus mouse software $(7,25)$. Prior to scanning, mice were anesthetized with an intramuscular injection of $0.1 \mathrm{~mL} / 100 \mathrm{~g}$ body weight of mouse cocktail containing Ketamine/Xylazine/PBS (3:2:5, by vol). Upon completion of scanning, BMD was determined in the following bone areas using the PIXImus software, version 2.1: distal femoral metaphysis (DFM) (knee joint) to include cancellous (trabecular) bone, proximal tibial metaphysis (PTM) and femoral diaphysis (FD). Intra-scan coefficients of variation were $0.79 \%, 3.30 \%$ and $1.35 \%$ for DFM, PTM, and FD respectively; interscan coefficients of variation were $5.47 \%, 3.86 \%$, and $5.12 \%$ for DFM, PTM and FD respectively. The coefficients of variation are in agreement with studies examining the precision and accuracy of the PIXImus densitometer (28).

\subsection{Intravenous glucose tolerance test (IVGTT)}

IVGTT was performed after 20 weeks using 6 mice from each dietary group. For the IVGTT, 6 h-fasting mice were anesthetized with an intramuscular injection of $0.1 \mathrm{ml} / 100 \mathrm{~g}$ body weight of mouse cocktail containing Ketamine/Xylazine/PBS (3:2:5, by vol). Blood sample was drawn from the retrobulbar, intraorbital, capillary plexus followed by intravenous injection of D-glucose $(1 \mathrm{~g} / \mathrm{kg}$ ) into the tail vein (volume load $10 \mu \mathrm{l} / \mathrm{g}$ ). Blood samples were again drawn 5, 10, 20, 50, and 75 min after the glucose injection. After immediate centrifugation at $4{ }^{\circ} \mathrm{C}$, serum was collected and stored at $-80^{\circ} \mathrm{C}$.

\subsection{Blood and tissue collection for biochemical and histological analysis}

After 6 months on the experimental diet, the animals were sacrificed. One week prior to sacrifice, mice were fasted for 6-8 hrs, blood samples were taken from the intraorbital, retrobulbar plexus from anesthetized mice to measure fasting glucose, insulin and nonesterified fatty acid in serum (NEFA). At the end of 6 months, the mice were anaesthetized and blood was obtained by intraorbital capillary plexus. Serum was collected and stored at $-80^{\circ} \mathrm{C}$. Liver, gastrocnemius and quadriceps muscles were collected, weighed and frozen in 
liquid nitrogen and stored in $-80^{\circ} \mathrm{C}$. Spleen, tibia and femur were processed for subsequent splenocyte culture and BM culture respectively. Right side of complete hind leg was fixed in $4 \%$ formalin and processed for Oil Red O staining to measure BM adiposity after dietary intervention.

\subsection{Measurement of serum metabolites}

Serum glucose (QuantiChrom, Hayward, CA), triglycerides (TGs) (Cayman Chemical Company, MI), NEFA (Wako Pure Industries Ltd, Japan), catalase and malondialdehyde (MDA), (Cell Biolabs Inc., CA) were analyzed spectrophotometrically using Colorimetric Assay Kits following manufacturers' protocol. Insulin was analyzed using a rat/mouse Ultra sensitive rat insulin ELISA kit (Crystal Chem Inc. Research, Downers Grove, IL). Adiponectin and leptin were analyzed by using ELISA kits (R\&D systems Inc., Minneapolis, MN) following manufacturer's protocol.

\subsection{Splenocytes preparation and culture}

Spleen was aseptically removed and placed in $5 \mathrm{ml}$ of RPMI 1640 medium (Gibco, Grand Island, NY) supplemented with $25 \mathrm{mmol} / \mathrm{L}$ HEPES, $2 \mathrm{mmol} / \mathrm{L}$ glutamine, 100,000 U/L penicillin and $100 \mathrm{mg} / \mathrm{L}$ streptomycin (Gibco, Grand Island, NY). Single-cell suspensions were made by teasing spleens between frosted ends of two sterile glass slides. After a 5-min centrifugation at $1000 \mathrm{rpm}$ to separate cells from debris, the cells were washed twice in RPMI medium. Splenic lymphocytes were isolated by layering over Histopaque (Sigma, St. Louis, MO), centrifuging at $1000 \mathrm{rpm}$ for $15 \mathrm{~min}$ at $22^{\circ} \mathrm{C}$ followed by washing twice in RPMI 1640 complete medium. Cells were counted, and viability was determined by trypan blue exclusion method (25).

\subsection{Isolation of whole BM cells and culture}

Whole BM cells were aseptically isolated as described (25). In brief, cells were counted and viability was determined by trypan blue exclusion method. Cells $\left(10 \times 10^{6} /\right.$ well $)$ were plated in 12 well plates and bacterial LPS was added at the concentration of $5.0 \mu \mathrm{g} / \mathrm{ml}$ for $24 \mathrm{~h}$ at $37^{\circ} \mathrm{C}$ in a humidified atmosphere of air/ $\mathrm{CO}_{2} 95: 5(\mathrm{~mol} \%)$. After $24 \mathrm{~h}$, cells and culture medium were collected together and centrifuged at $2000 \mathrm{rpm}$ for $5 \mathrm{~min}$. The pellets were stored at $-80^{\circ} \mathrm{C}$ for gene expression assays and supernatants were analyzed for TNF- $\alpha$ and IL-6. BM cells cytosolic extract were used to measure the levels of MDA, catalase and SOD.

\subsection{Hematoxylin and eosin (H\&E) staining of liver tissue}

After animal sacrifice, liver tissues were excised and fixed in $10 \%$ formalin for $24 \mathrm{hrs}$ at room temperature (RT). Tissue was then embedded in paraffin following conventional methods. $5 \mu \mathrm{m}$ sections were made and stained with H\&E staining procedure for subsequent histological analysis.

\subsection{Cathepsin K (ctsk) and PPARy gene expression in BM cells by real time RT-PCR}

mRNA expression for genes encoding ctsk and PPAR $\gamma$ were measured using real time RTPCR. Frozen bacterial LPS-stimulated BM cells were vortexed in lysis buffer and RNA was isolated using RNeasy Mini Kit following the manufacturer's instructions (Qiagen, Valencia, CA). Total RNA concentration was assessed in NanoDrop ${ }^{\mathrm{TM}} 1000$ spectrophotometer (Thermo Scientific, Wilmington, DE, USA). Real time RT-PCR was carried out using TaqMan ${ }^{\circledR}$ RNA-to- $\mathrm{C}_{\mathrm{T}}$ 1-step kit (Applied Biosystems, Foster City, CA) in an ABI Prism 7900HT Sequence Detection System (Applied Biosystems) using fluorescent TaqMan methodology. Real time quantitative PCR was performed for each of the following genes, using ready-to-use primer and probe sets predeveloped by Applied Biosystems 
(TaqMan Gene Expression Assays) were used to quantify ctsk (Ctsk, Mm00484036_m1), peroxisome proliferators-activated receptor $\left(\mathrm{PPAR}_{\gamma}\right)\left(\right.$ ppar $_{\gamma}, \mathrm{Mm01184321 \_ \textrm {m } 1 ) \text { and }}$ Glyceraldehyde-3-phosphate dehydrogenase (Gapdh, Mm99999915_g1) as an endogenous control. mRNA Ct values for these genes were normalized to the house-keeping gene GAPDH and expressed as relative increase or decrease compared to the CO group.

\subsection{Histological evaluation of femur head for bone adiposity by Oil Red $\mathrm{O}$ staining}

Formalin fixed hind leg bones were placed in saturated solution of linoleic acid in ethylene glycol $(500 \mathrm{ml}$ of $70 \%$ ethylene glycol and $5 \mathrm{~g}$ of linoleic acid were mixed for one hr at RT, allowed to stand for several hrs at RT in a separating funnel, and the bottom layer drawn off) for 3 days at $56^{\circ} \mathrm{C}$. Bones were then sequentially rinsed for $8 \mathrm{hrs}$ each in several changes of $70 \%$ ethanol at RT followed by with several changes of water. The bones were decalcified in $2 \%$ chromic acid for $40 \mathrm{hrs}$ at $4{ }^{\circ} \mathrm{C}$ followed by rinsing with water for $8 \mathrm{hrs}$ and incubation with $5 \%$ aqueous sodium bicarbonate for $24 \mathrm{hrs}$ at RT. The bones were finally rinsed with several changes of water for 24-72 hrs at RT. Bones were then placed in 70\% ethanol and processed, embedded in paraffin and stained with $0.5 \%$ Oil Red O in isopropanol (w/v) for $10 \mathrm{~min}$. Lipid vacuole area were assessed using a light microscope with a digitalized camera and a Metaview image analysis system (Olympus America Inc, PA). The area of lipid vacuoles was calculated from six different fields.

\subsection{Measurement of malondialdehyde (MDA) levels, catalase (CAT) and superoxide dismutase (SOD) activity in BM cells}

After 24 hrs BM cells treated with bacterial LPS were used to prepare cytosolic extracts using a Nuclear Extract Kit from Active Motive (Carlsbad, CA), following manufacturer's protocol. Fifty micrograms of cytosolic extracts were used to determine MDA levels, CAT and SOD activities using commercially available kits.

\subsection{Cytokines measurement in serum, conditioned medium of cultured splenocytes and BM cells}

Isolated BM cells and splenocytes $\left(10 \times 10^{6}\right.$ cells/well $)$ were plated in 6-well plates and incubated with $5.0 \mu \mathrm{g} / \mathrm{ml}$ of bacterial lipopolysaccharide (LPS) for $24 \mathrm{~h}$ at $37^{\circ} \mathrm{C}$ in a humidified atmosphere of air/ $\mathrm{CO}_{2}$ 95:5 (mol\%). After $24 \mathrm{~h}$, the culture medium was collected and analyzed for TNF- $\alpha$ and IL-6 by Ready-set-go ELISA kits (eBioscience, Inc. San Diego, CA) following manufacturer's protocol.

\subsection{Statistical analysis}

Data are presented as mean values \pm SEM. Differences among the groups (CO, FO, CLA and $\mathrm{CLA}+\mathrm{FO}$ ) were tested by one-way analysis of variance (ANOVA) followed by Newman-Keuls multiple comparison post-hoc test. A p value $\mathrm{P} \leq 0.05$ was considered statistically significant. The analyses were performed using Graphpad prism for Windows (La Jolla, CA, USA).

\section{Results}

\subsection{Effect of CLA+FO on body weights and CLA-induced liver enlargement}

The initial body weights for 12 months old C57B1/6J mice in CO, FO, CLA and CLA+FO groups were $25.59 \pm 0.60,24.84 \pm 0.79,25.17 \pm 0.26$ and $24.50 \pm 0.61 \mathrm{~g}$ respectively. Chronic six months feeding of CLA and CLA+FO caused a significant reduction $(\mathrm{P}<0.05)$ in body weight gain when compared to CO fed mice (Figure 1A). The CLA-fed mice showed a $6 \%$ weight gain compared to $28 \%$ in CO-fed mice, the difference between the two being very highly significant $(\mathrm{P}<0.01)$. Similarly, CLA+FO fed group showed lowered body weight 
gain (9\%) compared to $\mathrm{CO}$ fed group (28\%). However, no significant change in body weight gain (27\%) was observed in mice fed FO alone. The CLA fed mice showed significant increase in liver weight compared to $\mathrm{CO}, \mathrm{FO}$ and $\mathrm{CLA}+\mathrm{FO}$ fed mice. The liver weight in CLA fed mice was $2.17 \pm 0.10 \mathrm{~g}$, which was significantly higher $(\mathrm{P}<0.001)$ than that of $\mathrm{CO}$, $\mathrm{FO}$, and CLA+FO fed mice in which livers weighed $1.43 \pm 0.06,1.12 \pm 0.1$ and $1.38 \pm 0.09 \mathrm{~g}$ respectively (Figure 1B). The data of the present study confirmed that CLA-induced liver enlargement in $\mathrm{C} 57 \mathrm{B1} / 6 \mathrm{~J}$ aging mice is prevented by supplementation with $\mathrm{FO}$ whereas the FO-induced body weight gain is thwarted by CLA.

\subsection{Histological changes in CLA-induced fatty liver by CLA+FO}

Histological sections of liver tissue from CO and CLA-fed mice showed predominantly large lipid-filled vacuoles (macrovesicular steatosis) Figure 1C. Liver sections from FO and $\mathrm{CLA}+\mathrm{FO}$ group revealed a reduction of lipid accumulation, in the form of lipid droplets, or even small lipid droplets (microvesicular steatosis). The histomorphometric analysis using microscopy of lipid vacuole area revealed visibly significant differences between the different groups where the lipid vacuole areas in CO, CLA, FO and CLA+FO fed mice livers were $5.49 \pm 0.4 \mu \mathrm{m}^{2}, 24.59 \pm 0.6 \mu \mathrm{m}^{2}, 0.31 \pm 0.1 \mu \mathrm{m}^{2}$ and $0.96 \pm 0.1 \mu \mathrm{m}^{2}$ respectively (Figure 1C). The lipid areas were significantly $(\mathrm{P}<0.001)$ higher and larger in $\mathrm{CO}$ and CLA fed mice compared to that of FO and CLA+FO fed mice, confirming that FO prevented CLA-induced liver steostasis.

\subsection{Improvement of insulin resistance by CLA+FO}

The higher circulating levels of NEFA in CO fed mice represents insulin resistance, which is strongly associated with obesity, and one of the mechanism may be the generation of metabolic messengers, such as free fatty acids, by adipose tissue that inhibit insulin action on muscle (29). The fasting serum glucose concentration increased significantly $(\mathrm{P}<0.05)$ in $\mathrm{CO}$ and CLA fed mice compared to FO and CLA+FO fed mice (Figure 2A). Contrarily, fasting serum insulin concentration also increased in mice treated with CLA for six months, demonstrating hyperinsulinemia which is comparable to CO. However, in CLA+FO fed mice, increased insulin level was associated with reduction in blood glucose concentration suggesting its ability to control hyperglycemia unlike CLA. The serum TGs were significantly $(\mathrm{P}<0.05)$ decreased in FO, CLA and CLA+FO compared to CO fed mice (Table 2). Surprisingly, fatty liver was observed in CLA fed mice, despite a reduction in TGs levels compared to CO fed mice. Finally, CLA+FO decreased TG levels, improved insulin levels and reduced glucose levels compared to $\mathrm{CO}$ as well as CLA. Fasting serum NEFA was also found to be significantly $(\mathrm{P}<0.05)$ decreased in FO and CLA+FO fed mice compared to $\mathrm{CO}$ group (Table 2). Furthermore, adiponectin levels (Table 2) were significantly $(\mathrm{P}<0.03)$ increased in CLA+FO fed mice compared to $\mathrm{CO}$ fed mice in contrast to leptin levels which were reduced significantly $(\mathrm{P}<0.05)$ in $\mathrm{CLA}+\mathrm{FO}$ than $\mathrm{CO}$. These results suggest an affirmative role of CLA+FO in improving CLA-induced insulin resistance and dysmetabolism in high fat fed $\mathrm{C} 57 \mathrm{Bl} / 6 \mathrm{~J}$ aging mice.

\subsection{Intravenous glucose tolerance test (IVGTT)}

The IVGTT was performed at 20 weeks of feeding of experimental diet. At 5, 10 and 20 minutes after IV injection of glucose, the CLA+FO fed mice eliminated glucose faster than $\mathrm{CO}$ and CLA fed mice. In contrast, the CO and CLA fed mice showed lesser elimination of glucose, at both 50 and 75 minute time points (Figure 3A), although a higher concentration of insulin was observed at these points. Thus, taken together, the basal levels of glucose and insulin, as a result of glucose challenge, demonstrated that CLA and CO treated mice display a more extensive impairment of $\beta$-cell function and, consequently, an exaggerated insulin resistance compared with $\mathrm{CLA}+\mathrm{FO}$ fed mice. The 5-min insulin response to intravenous glucose challenge was increased rapidly to $1.63 \pm 0.04(\mathrm{ng} / \mathrm{ml})$ in $\mathrm{CO}$ and 
$1.78 \pm 0.35$ (ng/ml) in CLA fed mice, however, it was apparently insufficient to maintain normal glucose tolerance. A more pronounced and significant $(\mathrm{P}<0.05)$ increase in insulin secretion was observed by glucose challenge in CLA fed mice demonstrating hyperinsulinemia Figure 3B, unlike in CLA+FO fed mice.

\subsection{CLA+FO increases BMD in femur and tibia regions measured by DXA}

Baseline BMD of different bone regions measured prior to the start of the experimental diet showed no differences among the groups. To examine the effect of CLA+FO on ageassociated bone loss, we measured the BMD after feeding the experimental diet for 6 months, using DXA. The results are expressed as \% difference, as shown in Figure 4A, B and $\mathrm{C}$. The BMD in the distal end of the femoral metaphysis (DFM), proximal end of the tibial metaphysis (PTM), and the femoral diaphysis (FD) regions of the FO, CLA and CLA $+\mathrm{FO}$ fed mice was significantly higher $(\mathrm{P}<0.01)$ than that of $\mathrm{CO}$ fed mice. These findings indicate that 12 months old mice, when placed on $\mathrm{CO}$ enriched diet for 6 months, resulted in bone loss (25), which was restored by FO, CLA and CLA+FO dietary intervention.

\subsection{Reduction of BM adiposity by CLA+FO}

Oil Red O staining of femoral head from 18 months old mice fed an experimental diet for 6 months, revealed a significant $(\mathrm{P}<0.01)$ increase in vacuole area of adipocytes (Figure 4D), in $\mathrm{CO}\left(1.22 \pm 0.7 \mu \mathrm{m}^{2}\right)$ and FO $\left(1.4 \pm 0.6 \mu \mathrm{m}^{2}\right)$ fed mice when compared to CLA $(0.09 \pm 0.03$ $\left.\mu \mathrm{m}^{2}\right)$ and CLA+FO $\left(0.18 \pm 0.04 \mu \mathrm{m}^{2}\right)$ fed mice. Bone forming osteoblasts and fat forming adipocytes are both derived from mesenchymal stem cells (MSCs) (30), which are found in many tissues and are abundant in the BM stroma (31). Of note, the fat cell size was also reduced in FO, CLA and $\mathrm{CL}+\mathrm{FO}$, which is important determinant of age-related adiposity (32). Reduction of BM adiposity in the femur head section revealed the positive role of CLA, CLA+FO and FO fed mice in the prevention of age-associated bone loss (Figure 4E).

\subsection{CLA+FO decreases total body fat mass (BFM) and increases HLLM measured by DXA}

Total BFM was decreased (Figure 5A) and HLLM was significantly $(\mathrm{P}<0.05)$ increased (Figure 5B) in CLA and CLA+FO fed mice compared to CO fed mice. Furthermore, we noted the skeletal muscle wet weight of quadriceps and gastrocnemius muscles were moderately increased (not significant, data not shown) in CLA and CLA+FO fed mice. The increased weight of the skeletal muscle, showed by DXA analysis demonstrated a significant $(\mathrm{P}<0.05)$ increase in HLLM in CLA $(9 \%)$ and CLA+FO (10\%) fed mice compared to that in $\mathrm{CO}(-10 \%)$ fed mice (Figure 5B).

\subsection{Gene expression by LPS-stimulated BM cells}

Quantitative real time RT-PCR further demonstrated that, bacterial LPS-stimulated mRNA expression of $c t s k$ was significantly decreased $(\mathrm{P}<0.05)$ in $\mathrm{BM}$ from FO, CLA and CLA+FO groups as compared to that in $\mathrm{CO}$ group, demonstrating that FO, CLA or their combination decrease osteoclastogenic bone resorption, thus improving BMD (Figure 6A). Attempts were made to determine the RUNX2 mRNA expression, however, the levels were not detectable in BM cells (Data not shown). Additionally, the PPAR $\gamma$ expression was significantly $(\mathrm{P}<0.05)$ decreased in FO, CLA and $\mathrm{CLA}+\mathrm{FO}$ fed mice compared to that in $\mathrm{CO}$ fed mice (Figure 6B). An additive inhibitory effect on PPAR $\gamma$ expression was observed in $\mathrm{CLA}+\mathrm{FO}$ fed mice. The inhibitory effects of CLA+FO on ctsk and PPAR $\gamma$ in BM cells confirmed their possible protective effect against bone resorption in aging mice.

\subsection{CLA+FO decreases MDA levels and increases catalase activity in BM cells}

The $\mathrm{CO}$ diet fed mice showed a significant $(\mathrm{P}<0.02)$ increase in MDA levels compared to FO, CLA and CLA+FO fed mice. In contrast, anti-oxidant enzyme CAT activity was 
significantly $(\mathrm{P}<0.001)$ increased in FO, CLA and CLA+FO fed mice groups when compared to $\mathrm{CO}$ fed mice (Figure 6C and $\mathrm{D}$ ). Even though, there was increase in superoxide dismutase activity in FO, CLA and CLA+FO fed mice, it was not significantly different from that in $\mathrm{CO}$ fed mice. It is established that osteoporotic women have significantly reduced antioxidant enzyme activity and increased lipid peroxidation end-product, like MDA (33). Previous reports have shown that reactive oxygen species such as superoxide anion are involved in the pathogenesis of bone loss by stimulating osteoclast differentiation and bone resorption (34). These results indicated that a combination of CLA+FO may suppress osteoclastic bone resorption in mice by inhibiting the reactive free radicals or lipid peroxidation.

\subsection{Effect of CLA+FO on LPS-stimulated pro-inflammatory cytokines production by splenocytes and BM cells}

We observed protective effect of CLA+FO against age-associated BMD-loss in mice, through the regulation of bone-resorbing, inflammatory cytokines expression. Proinflammatory cytokines such as, IL-6 and TNF- $\alpha$, are key regulators of osteoclastogenic activity and have been shown to increase bone resorption with age in humans (35). Interestingly, we found significant $(\mathrm{P}<0.04)$ decrease in IL- 6 and TNF- $\alpha$ production in LPStreated splenocytes (Figure $7 \mathrm{~A}$ and $\mathrm{B}$ ) and BM cells (Figure $7 \mathrm{C}$ and D) of CLA+FO fed mice compared to that in $\mathrm{CO}$ fed mice. These results indicate that the reduction of proinflammatory cytokines by BM and splenocytes may prevent age-associated bone loss indirectly by inhibiting bone resorbing osteoclastogenesis.

\section{Discussion}

Given the escalating prevalence of overweight population and osteoporosis worldwide, it would be advantageous to identify potential therapeutic nutrients/functional foods capable of decreasing fat mass as well as preventing bone loss. CLA is widely used in weight loss management and to reduce fat mass $(12,36)$, which is the principal etiological factor of the metabolic syndrome like insulin resistance and type 2 diabetes. CLA has been known to improve BMD in animals (13). However, supplementation with CLA or its t10,c12 isomer is associated with induction of insulin resistance and transmigration of lipids to liver resulting in hepatic steostasis (14). In this investigation, attempts have been made to reduce CLAinduced liver hypertrophy and insulin resistance by incorporating FO in the CLA supplemented diet, as FO is also known to reduce TGs and improve insulin sensitivity, as well as BMD. Additionally, we have ascertained the novel use of CLA with FO in maintaining BMD and muscle mass in high fat diet fed C57Bl/6J aging mice.

In this dietary intervention study, we demonstrated that combination of CLA and FO alleviates CLA-induced insulin resistance and hepatic steatosis in C57Bl/6J aging mice. Importantly, in addition to that, it also helps to prevent age-associated bone loss, decrease fat mass and increase hind leg lean mass. These beneficial effects on age-associated bone loss were associated with increased BMD, decreased BM adiposity and down-regulation of genes involved in osteoclastogenesis, as well as osteotropic factors, such as TNF- $\alpha$ and IL-6. Furthermore, $\mathrm{CLA}+\mathrm{FO}$ induced the production of potent anti-inflammatory, antisteatotic, insulin-sensitizing adipokine, e. g. adiponectin.

Non-Alcoholic Fatty Liver Disease (NAFLD) is distinctive among liver diseases, because its etiology is closely related to the metabolic syndrome (37), observed similarly in CLA $(14,38)$. Much of the increased prevalence of NAFLD is driven by weight gain particularly in aging (37) in which visceral fat is the most important factor for the development of hepatic steatosis (39) in obese people. Interestingly, CLA reduces visceral fat, but develops insulin resistance, which is commonly observed in CLA fed mice $(14,40)$, and humans 
$(16,41)$. Indeed, it has been reported that in the absence of obesity, even in patients with total lipodistrophy, insulin resistance leads to hepatic steatosis $(42,43)$. Although the mechanisms underlying the association of insulin resistance and hepatic steatosis remain unclear, altered insulin sensitivity has been shown to increase hepatic de novo lipogenesis and to induce lipolysis of adipocyte TGs and flux of free fatty acids to the liver (44). Our results showed a significant improvement in the glucose tolerance test curves in high fat diet fed C57B6J aging mice supplemented with CLA+FO, presumably by decreasing TGs levels, and by inducing glucose uptake and insulin-signaling components which in turn contributes to the antisteatotic actions of FO+CLA. It is established by a number of investigators that FO supplementation increases adiponetin levels $(45,46)$ and up-regulates $\mathrm{PPAR}_{\alpha}$, a key gene involved in the control of hepatic peroxisomal $\beta$-oxidation of fatty acids (47). DHA, a strong PPAR $\gamma$ activator, arouses further interest in developing FO derivatives as a potent antidiabetic drug, without producing undesirable effects, such as obesity and hepatotoxicity (48).

It was previously believed that obesity and osteoporosis were two unrelated diseases. But recent studies have shown that both diseases share several common genetic and environmental factors $(2,25)$. The common precursor mesenchymal stem cells (MSCs) (30) that leads to the differentiation of both adipocytes and osteoblasts, as well the secretion of adipocyte-derived hormones that affect bone metabolism, may partially explain these associations. Recently Naveiras et al suggested that adipocytes in BM alter the microenvironment and may have negative consequences for the skeleton. Fat overload would replace functional hematopoietic and/or osteogenic cells from the BM cavity (49). Reduction of adipose tissue in femur head bone sections suggests the possible role of CLA $+\mathrm{FO}$ in osteoblast formation. Number of studies on adipocyte function has revealed that adipose tissue is not just an inert organ for energy storage, but acts as an endocrine organ (50)capable of expression and secretion of a variety of biologically active molecules, such as estrogen, resistin, leptin, adiponectin, IL-6, TNF- $\alpha$ etc,) (50). These molecules affect human energy homeostasis and also may be involved in bone metabolism, which may contribute to the complex relationship between fat mass and bone. Body fat mass, a component of body weight, is one of the most important indices of obesity, and a substantial body of evidence indicates that fat mass may have beneficial effects on bone (2). However, in our studies CO fed obese mice exhibited reduced BMD compared to FO, CLA and FO+CLA fed mice. Based on our current state of knowledge, it is unclear whether fat has beneficial effects on bone. We anticipate that this will be an active and fruitful focus of research in the coming years.

Previous work in our laboratory has demonstrated a reduction in ovariectomy-induced BMD loss in mice by dietary FO, accompanied by decreased osteoclastogenesis (7), and also revealed this molecular mechanism by using a fat- 1 transgenic mouse model which has the inherent ability to produce n-3 fatty acids from n-6 fatty acids (51). Importantly, our group also showed the beneficial effect of FO on bone mass during aging, by modulating bone formation and bone resorption factors (52). Furthermore, feeding CLA diet in middle-age mice suggests that the loss of bone and muscle may be prevented by modulating the markers of inflammation and osteoclastogenic factors (13). In this current study, we revealed that ctsk, which is abundant in osteoclast, plays a vital role in bone resorption (53), and was down-regulated in CLA+FO fed mice, demonstrating that prevention of age-associated bone loss might be related to bone resorption. It is established that oxidative stress is negatively associated with bone loss (54). Decreased oxidative stress, as measured by MDA levels and increased CAT activity explains partly the mechanism of bone loss prevention by CLA+FO supplementation. 
The results of the current study strongly support the concept that an increased intake of FO would contribute to the prevention of age-associated bone loss and to the prevention of CLA-induced insulin resistance and metabolic liver disease (55), similar to the improved outcomes reported in cardiovascular disease, arthritis, cystic fibrosis, IgA nephropathy, diabetes, ulcerative colitis, Crohn's disease, asthma, and sepsis (24). Our results are consistent with previous investigations reporting that CLA-induced hepatomegaly can be prevented using FO $(56,57)$ and flaxseed oil (55). Additionally, our studies revealed that, $\mathrm{CLA}+\mathrm{FO}$ increases BMD by decreasing the BM adiposity in the femur bone; FO, in combination with CLA, decreases the inflammation status by reducing the pro-inflammatory cytokines (TNF- $\alpha$, and IL-6) and eventually, reduction in oxidative stress which partially explain the mechanism of bone loss prevention by CLA+FO.

In summary, age-associated protection of bone loss by individual fatty acids such as CLA (13), FO (52) and also combination of FO with CLA is associated with decreased total fat mass in mice (57) in agreement with human studies (56) further confirming the benefits of FO supplementation in CLA-induced liver hypertrophy and insulin resistance. Additionally, $\mathrm{CLA}+\mathrm{FO}$ significantly contributed to the prevention of BM adiposity and increased hind leg lean mass in aging mice. In conclusion, this finding provides a strong and compelling rationale for dietary supplementation of FO during clinical trial with CLA in obese, insulinresistant aging patients in order to prevent osteoporosis. Additional studies in higher species and humans are still needed before the use of CLA+FO, as a dietary supplement to reduce obesity and osteoporosis in humans.

\section{Acknowledgments}

Funding source: R21 AG027562 and 1R01AT004259-01 NIH grants to GF

\section{REFERENCES}

1. Di Iorgi N, Rosol M, Mittelman SD, Gilsanz V. Reciprocal relation between marrow adiposity and the amount of bone in the axial and appendicular skeleton of young adults. J Clin Endocrinol Metab. 2008; 93:2281-6. [PubMed: 18381577]

2. Zhao LJ, Jiang H, Papasian CJ, et al. Correlation of obesity and osteoporosis: effect of fat mass on the determination of osteoporosis. J Bone Miner Res. 2008; 23:17-29. [PubMed: 17784844]

3. Boyle WJ, Simonet WS, Lacey DL. Osteoclast differentiation and activation. Nature. 2003; 423:337-42. [PubMed: 12748652]

4. Belury MA. Dietary conjugated linoleic acid in health: physiological effects and mechanisms of action. Annu Rev Nutr. 2002; 22:505-31. [PubMed: 12055356]

5. Bhattacharya A, Banu J, Rahman M, Causey J, Fernandes G. Biological effects of conjugated linoleic acids in health and disease. Journal of Nutritional Biochemistry. 2006; 17:789-810. [PubMed: 16650752]

6. Ruxton CH, Reed SC, Simpson MJ, Millington KJ. The health benefits of omega-3 polyunsaturated fatty acids: a review of the evidence. J Hum Nutr Diet. 2004; 17:449-59. [PubMed: 15357699]

7. Sun D, Krishnan A, Zaman K, Lawrence R, Bhattacharya A, Fernandes G. Dietary n-3 fatty acids decrease osteoclastogenesis and loss of bone mass in ovariectomized mice. J Bone Miner Res. 2003; 18:1206-16. [PubMed: 12854830]

8. Yaqoob P, Calder PC. N-3 polyunsaturated fatty acids and inflammation in the arterial wall. Eur J Med Res. 2003; 8:337-54. [PubMed: 12915325]

9. Mori TA, Bao DQ, Burke V, Puddey IB, Beilin LJ. Docosahexaenoic acid but not eicosapentaenoic acid lowers ambulatory blood pressure and heart rate in humans. Hypertension. 1999; 34:253-60. [PubMed: 10454450]

10. Montori VM, Farmer A, Wollan PC, Dinneen SF. Fish oil supplementation in type 2 diabetes: a quantitative systematic review. Diabetes Care. 2000; 23:1407-15. [PubMed: 10977042] 
11. 2008. http://www.foodnavigator-usa.com/Legislation/CLA-achieves-US-approval-for-usein-foods

12. Whigham LD, Watras AC, Schoeller DA. Efficacy of conjugated linoleic acid for reducing fat mass: a meta-analysis in humans. Am J Clin Nutr. 2007; 85:1203-11. [PubMed: 17490954]

13. Rahman MM, Bhattacharya A, Banu J, Fernandes G. Conjugated linoleic acid protects against ageassociated bone loss in C57BL/6 female mice. J Nutr Biochem. 2007; 18:467-74. [PubMed: 16997541]

14. Tsuboyama-Kasaoka N, Takahashi M, Tanemura K, et al. Conjugated linoleic acid supplementation reduces adipose tissue by apoptosis and develops lipodystrophy in mice. Diabetes. 2000; 49:1534-42. [PubMed: 10969838]

15. Moloney F, Yeow TP, Mullen A, Nolan JJ, Roche HM. Conjugated linoleic acid supplementation, insulin sensitivity, and lipoprotein metabolism in patients with type 2 diabetes mellitus. Am J Clin Nutr. 2004; 80:887-95. [PubMed: 15447895]

16. Riserus U, Vessby B, Arner P, Zethelius B. Supplementation with trans10cis12-conjugated linoleic acid induces hyperproinsulinaemia in obese men: close association with impaired insulin sensitivity. Diabetologia. 2004; 47:1016-9. [PubMed: 15168020]

17. Riserus U, Arner P, Brismar K, Vessby B. Treatment with dietary trans10cis12 conjugated linoleic acid causes isomer-specific insulin resistance in obese men with the metabolic syndrome. Diabetes Care. 2002; 25:1516-21. [PubMed: 12196420]

18. DeLany JP, Blohm F, Truett AA, Scimeca JA, West DB. Conjugated linoleic acid rapidly reduces body fat content in mice without affecting energy intake. Am J Physiol. 1999; 276:R1172-9. [PubMed: 10198400]

19. Poirier H, Niot I, Clement L, Guerre-Millo M, Besnard P. Development of conjugated linoleic acid (CLA)-mediated lipoatrophic syndrome in the mouse. Biochimie. 2005; 87:73-9. [PubMed: 15733740]

20. Halade GV, Rahman MM, Fernandes G. Effect of CLA isomers and their mixture on aging C57B1/ 6J mice. Eur J Nutr. 2009; 48:409-18. [PubMed: 19424653]

21. Noto A, Zahradka P, Yurkova N, et al. Conjugated linoleic acid reduces hepatic steatosis, improves liver function, and favorably modifies lipid metabolism in obese insulin-resistant rats. Lipids. 2006; 41:179-88. [PubMed: 17707984]

22. Neschen S, Morino K, Dong J, et al. n-3 Fatty acids preserve insulin sensitivity in vivo in a peroxisome proliferator-activated receptor-alpha-dependent manner. Diabetes. 2007; 56:1034-41. [PubMed: 17251275]

23. Storlien LH, Kraegen EW, Chisholm DJ, Ford GL, Bruce DG, Pascoe WS. Fish oil prevents insulin resistance induced by high-fat feeding in rats. Science. 1987; 237:885-8. [PubMed: 3303333]

24. Calder PC. n-3 polyunsaturated fatty acids, inflammation, and inflammatory diseases. Am J Clin Nutr. 2006; 83:1505S-1519S. [PubMed: 16841861]

25. Halade GV, Rahman MM, Williams PJ, Fernandes G. High fat diet-induced animal model of ageassociated obesity and osteoporosis. J Nutr Biochem. (In press).

26. Surwit RS, Kuhn CM, Cochrane C, McCubbin JA, Feinglos MN. Diet-induced type II diabetes in C57BL/6J mice. Diabetes. 1988; 37:1163-7. [PubMed: 3044882]

27. Glatt V, Canalis E, Stadmeyer L, Bouxsein ML. Age-related changes in trabecular architecture differ in female and male C57BL/6J mice. J Bone Miner Res. 2007; 22:1197-207. [PubMed: 17488199]

28. Nagy TR, Clair AL. Precision and accuracy of dual-energy X-ray absorptiometry for determining in vivo body composition of mice. Obes Res. 2000; 8:392-8. [PubMed: 10968731]

29. Boden G. Role of fatty acids in the pathogenesis of insulin resistance and NIDDM. Diabetes. 1997; 46:3-10. [PubMed: 8971073]

30. Pittenger MF, Mackay AM, Beck SC, et al. Multilineage potential of adult human mesenchymal stem cells. Science. 1999; 284:143-7. [PubMed: 10102814]

31. Chen JL, Hunt P, McElvain M, Black T, Kaufman S, Choi ES. Osteoblast precursor cells are found in CD34+ cells from human bone marrow. Stem Cells. 1997; 15:368-77. [PubMed: 9323800] 
32. Yang H, Youm YH, Dixit VD. Inhibition of thymic adipogenesis by caloric restriction is coupled with reduction in age-related thymic involution. J Immunol. 2009; 183:3040-52. [PubMed: 19648267]

33. Ozgocmen S, Kaya H, Fadillioglu E, Aydogan R, Yilmaz Z. Role of antioxidant systems, lipid peroxidation, and nitric oxide in postmenopausal osteoporosis. Mol Cell Biochem. 2007; 295:4552. [PubMed: 16841180]

34. Garrett IR, Boyce BF, Oreffo RO, Bonewald L, Poser J, Mundy GR. Oxygen-derived free radicals stimulate osteoclastic bone resorption in rodent bone in vitro and in vivo. J Clin Invest. 1990; 85:632-9. [PubMed: 2312718]

35. Cheleuitte D, Mizuno S, Glowacki J. In vitro secretion of cytokines by human bone marrow: effects of age and estrogen status. J Clin Endocrinol Metab. 1998; 83:2043-51. [PubMed: 9626137]

36. Watras AC, Buchholz AC, Close RN, Zhang Z, Schoeller DA. The role of conjugated linoleic acid in reducing body fat and preventing holiday weight gain. Int J Obes (Lond). 2007; 31:481-7. [PubMed: 16924272]

37. Sevastianos VA, Hadziyannis SJ. Nonalcoholic fatty liver disease: from clinical recognition to treatment. Expert Rev Gastroenterol Hepatol. 2008; 2:59-79. [PubMed: 19072371]

38. Degrace P, Demizieux L, Gresti J, Chardigny JM, Sebedio JL, Clouet P. Hepatic steatosis is not due to impaired fatty acid oxidation capacities in C57BL/6J mice fed the conjugated trans-10,cis-12-isomer of linoleic acid. J Nutr. 2004; 134:861-7. [PubMed: 15051838]

39. Koda M, Kawakami M, Murawaki Y, Senda M. The impact of visceral fat in nonalcoholic fatty liver disease: cross-sectional and longitudinal studies. J Gastroenterol. 2007; 42:897-903. [PubMed: 18008034]

40. Warren JM, Simon VA, Bartolini G, Erickson KL, Mackey BE, Kelley DS. Trans-10,cis-12 CLA increases liver and decreases adipose tissue lipids in mice: possible roles of specific lipid metabolism genes. Lipids. 2003; 38:497-504. [PubMed: 12880104]

41. Riserus U, Smedman A, Basu S, Vessby B. Metabolic effects of conjugated linoleic acid in humans: the Swedish experience. Am J Clin Nutr. 2004; 79:1146S-1148S. [PubMed: 15159248]

42. Angulo P. Nonalcoholic fatty liver disease. N Engl J Med. 2002; 346:1221-31. [PubMed: 11961152]

43. Sanyal AJ. AGA technical review on nonalcoholic fatty liver disease. Gastroenterology. 2002; 123:1705-25. [PubMed: 12404245]

44. Guilherme A, Virbasius JV, Puri V, Czech MP. Adipocyte dysfunctions linking obesity to insulin resistance and type 2 diabetes. Nat Rev Mol Cell Biol. 2008; 9:367-77. [PubMed: 18401346]

45. Flachs P, Mohamed-Ali V, Horakova O, et al. Polyunsaturated fatty acids of marine origin induce adiponectin in mice fed a high-fat diet. Diabetologia. 2006; 49:394-7. [PubMed: 16397791]

46. Duda MK, O'Shea KM, Lei B, et al. Dietary supplementation with omega-3 PUFA increases adiponectin and attenuates ventricular remodeling and dysfunction with pressure overload. Cardiovasc Res. 2007; 76:303-10. [PubMed: 17643403]

47. Martin PG, Guillou H, Lasserre F, et al. Novel aspects of PPARalpha-mediated regulation of lipid and xenobiotic metabolism revealed through a nutrigenomic study. Hepatology. 2007; 45:767-77. [PubMed: 17326203]

48. Yamamoto K, Itoh T, Abe D, et al. Identification of putative metabolites of docosahexaenoic acid as potent PPARgamma agonists and antidiabetic agents. Bioorg Med Chem Lett. 2005; 15:517-22. [PubMed: 15664804]

49. Naveiras O, Nardi V, Wenzel PL, Hauschka PV, Fahey F, Daley GQ. Bone-marrow adipocytes as negative regulators of the haematopoietic microenvironment. Nature. 2009; 460:259-63. [PubMed: 19516257]

50. Greenberg AS, Obin MS. Obesity and the role of adipose tissue in inflammation and metabolism. Am J Clin Nutr. 2006; 83:461S-465S. [PubMed: 16470013]

51. Rahman MM, Bhattacharya A, Banu J, Kang JX, Fernandes G. Endogenous n-3 fatty acids protect ovariectomy induced bone loss by attenuating osteoclastogenesis. J Cell Mol Med. 2009

52. Bhattacharya A, Rahman M, Sun D, Fernandes G. Effect of fish oil on bone mineral density in aging C57BL/6 female mice. J Nutr Biochem. 2007; 18:372-9. [PubMed: 16963250] 
53. Saftig P, Hunziker E, Wehmeyer O, et al. Impaired osteoclastic bone resorption leads to osteopetrosis in cathepsin-K-deficient mice. Proc Natl Acad Sci U S A. 1998; 95:13453-8. [PubMed: 9811821]

54. Sheweita SA, Khoshhal KI. Calcium metabolism and oxidative stress in bone fractures: role of antioxidants. Curr Drug Metab. 2007; 8:519-25. [PubMed: 17584023]

55. Kelley DS, Vemuri M, Adkins Y, Gill SH, Fedor D, Mackey BE. Flaxseed oil prevents trans-10, cis-12-conjugated linoleic acid-induced insulin resistance in mice. Br J Nutr. 2009; 101:701-8. [PubMed: 18710604]

56. Sneddon AA, Tsofliou F, Fyfe CL, et al. Effect of a conjugated linoleic acid and omega-3 fatty acid mixture on body composition and adiponectin. Obesity (Silver Spring). 2008; 16:1019-24. [PubMed: 18356842]

57. Ide T. Interaction of fish oil and conjugated linoleic acid in affecting hepatic activity of lipogenic enzymes and gene expression in liver and adipose tissue. Diabetes. 2005; 54:412-23. [PubMed: 15677499] 
A

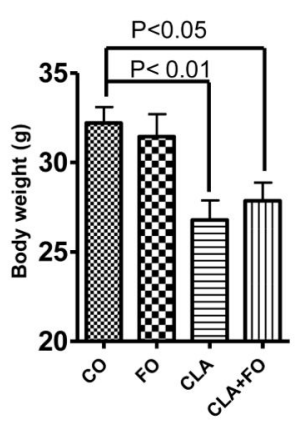

C

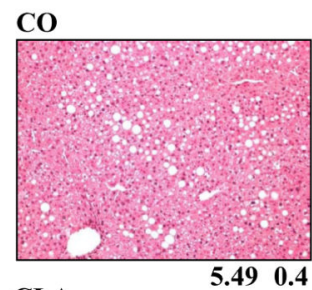

CLA

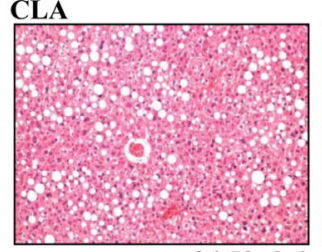

24.590 .6
B

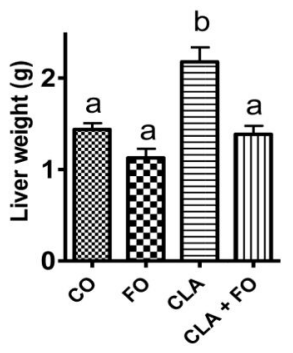

Figure 1.

Effect CO, FO, CLA and CLA+FO on body weight (A), liver weight (B) and liver histology (C). 12 month old C57Bl/6J mice $(n=10)$ were fed CO, FO, CLA and CLA+FO for 6 months. (C) Panels show hematoxylin and eosin (H\&E)-stained liver sections from representative mice ( $n=6$ /group). White circular area represents lipid. Values represent total lipid area $\left(\mu \mathrm{m}^{2}\right)$ by histomorphometry. Images are x200 magnifications. Values with different letters are significantly different by one way ANOVA followed by Newman-Keuls multiple comparison post-hoc test $(\mathrm{P}<0.05)$. 
A
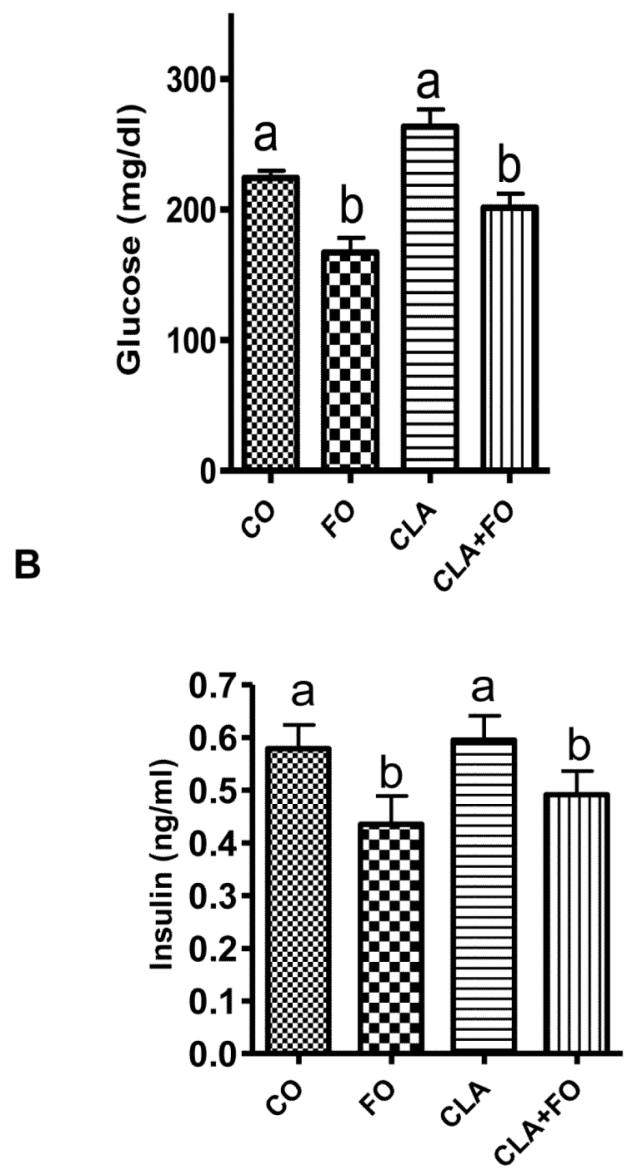

Figure 2.

Effect of CO, FO, CLA and CLA+FO on the fasting glucose (A) and Insulin (B). 12 month old C57Bl/6J mice $(n=10)$ were fed with CO, FO, CLA and CLA+FO for 6 months. Values with different letters are significantly different by one way ANOVA followed by NewmanKeuls multiple comparison post-hoc test $(\mathrm{P}<0.05)$. 
A

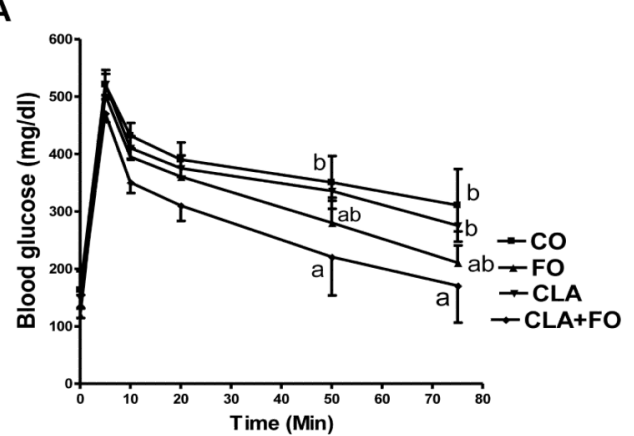

B

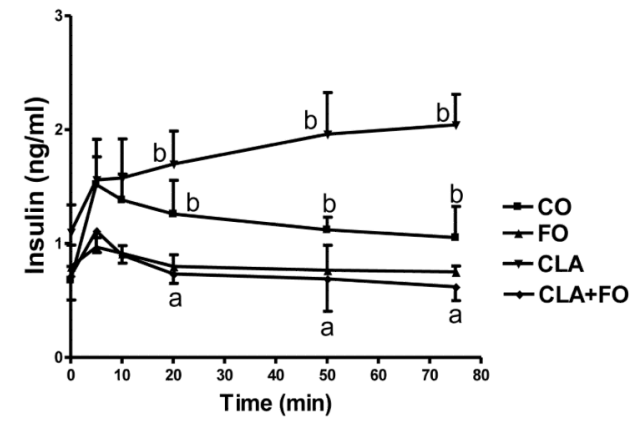

Figure 3.

Plasma levels of glucose (A) and insulin (B) after intravenous glucose administration: $1 \mathrm{~g} / \mathrm{kg}$ glucose was injected into the tail vein of mice fed with CO, FO, CLA and CLA+FO. The IVGTT was performed 5 months after starting the diets. Data are means \pm SEM from 6 independent experiments. Values with different letters are significantly different by one way ANOVA followed by Newman-Keuls multiple comparison post-hoc test $(\mathrm{P}<0.05)$. 


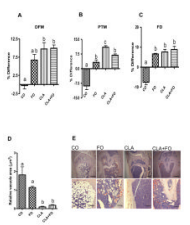

Figure 4.

Effect of CO, FO, CLA and CLA+FO on BMD of (A) distal femoral metaphysis (DFM), (B) proximal tibial metaphysis (PTM) and (C) femoral diaphysis (FD). Values represent percentage of change in BMD from baseline value determined at the beginning of the experiment. (D) Histomophometric evaluation of femoral adipocyte vacuole area $\left(\mu \mathrm{m}^{2}\right)$. (E) Representative photomicrographs of femoral head bone marrow adiposity - Femurs were processed after dietary supplementation of CO, FO, CLA and CLA+FO and stained with Oil Red O. Upper panel (4x, scale bar is $500 \mu \mathrm{m}$.) demonstrated reduced adiposity in CLA and $\mathrm{CLA}+\mathrm{FO}$ fed mice than $\mathrm{CO}$ and FO fed mice ( $n=5$ /group). Lower panel (10x, scale bar is $200 \mu \mathrm{m}$.) showed reduced adipocyte cell area in CLA and CLA+FO fed mice than CO and FO fed mice. 12 month old C57Bl/6J mice $(n=10)$ were fed with CO, FO, CLA and CLA + FO for 6 months. Values with different letters are significantly different by one way ANOVA followed by Newman-Keuls multiple comparison post-hoc test $(\mathrm{P}<0.05)$. 

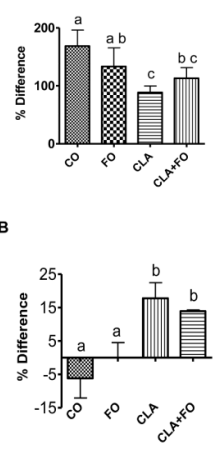

Figure 5.

Effect of CO, FO, CLA and CLA+FO on the total fat mass (A) and hind leg lean mass (B). 12 month old $\mathrm{C} 57 \mathrm{Bl} / 6$ mice $(\mathrm{n}=10)$ were fed with $\mathrm{CO}, \mathrm{FO}, \mathrm{CLA}$ and CLA+FO for 6 months. Values with different letters are significantly different by one way ANOVA followed by Newman-Keuls multiple comparison post-hoc test $(\mathrm{P}<0.05)$. 

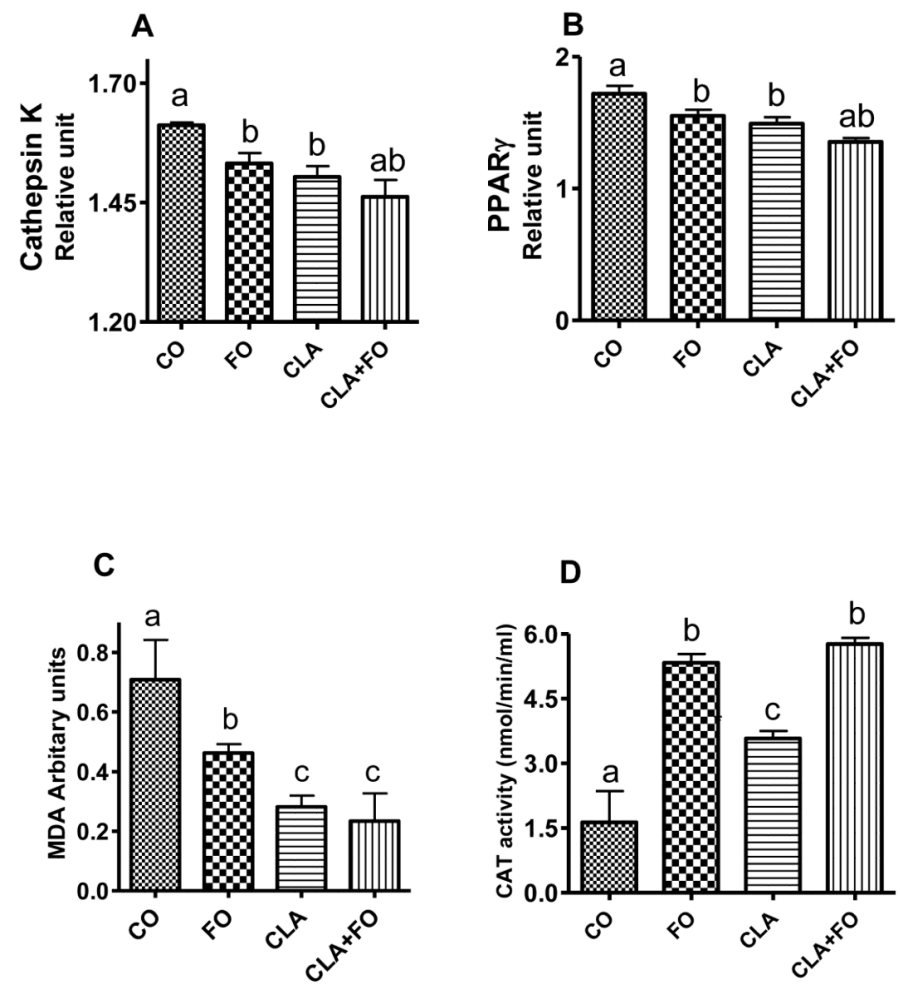

Figure 6.

CLA and CLA+FO down-regulate the expression of cathepsin K (A) and PPAR $\gamma(\mathrm{B})$.

Expression of osteoclast specific gene cathepsin K and adipocyte specific PPAR $\gamma$ in C57B1/ $6 \mathrm{~J}(\mathrm{n}=6)$ aging mice was determined by quantitative real-time RT-PCR in LPS-stimulated bone marrow cells from mice fed either fat diet $\mathrm{CO}$ as a control or diet enriched with $\mathrm{FO}$, CLA and CLA+FO for 6 months. MDA (C) and catalase (D) activity in bone marrow cells after dietary supplementation of $\mathrm{CO}, \mathrm{FO}, \mathrm{CLA}$ and CLA+FO in aging mice. 12 month old C57Bl/6J ( $n=6)$ mice were fed with CO, FO, CLA and CLA+FO for 6 months. Results are expressed as means \pm SEM; Values with different letters are significantly different by one way ANOVA followed by Newman-Keuls multiple comparison post-hoc test $(\mathrm{P}<0.05)$. 
A

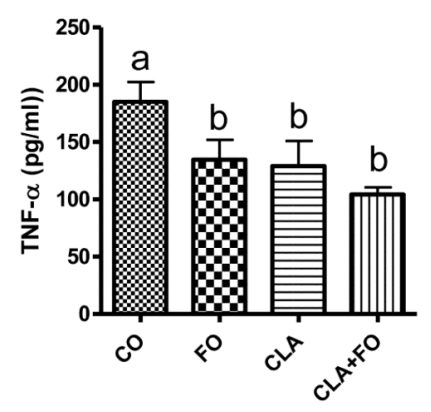

B

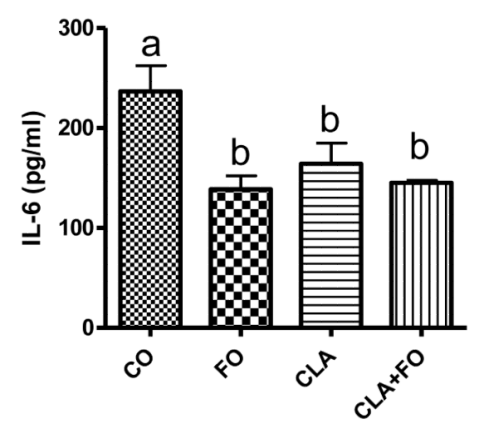

C

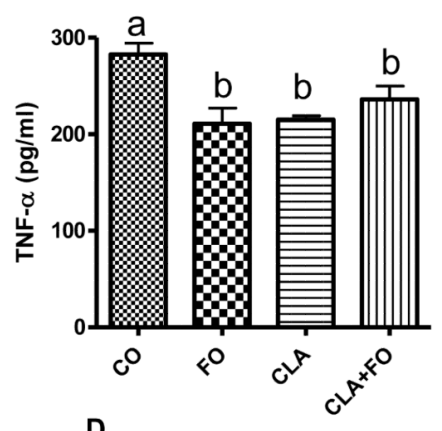

D

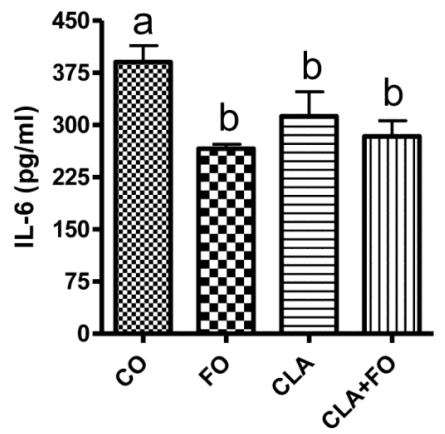

Figure 7.

Effect of CO, FO, CLA and CLA+FO on LPS-stimulated TNF- $\alpha$ and IL- 6 secretion by splenocytes (A and B) and bone marrow cells ( $\mathrm{C}$ and D). 12 month old $\mathrm{C} 57 \mathrm{Bl} / 6 \mathrm{~J}(\mathrm{n}=6)$ mice were fed with CO, FO, CLA and CLA+FO for 6 months and used for splenocytes and bone marrow cells culture. Values with different letters are significantly different by one way ANOVA followed by Newman-Keuls multiple comparison post-hoc test $(\mathrm{P}<0.05)$. 


\section{Table 1}

Composition of semi-purified experimental diets

\begin{tabular}{lc}
\hline Ingredients $^{a}$ & Percent \\
\hline Casein & 14.00 \\
Corn starch & 42.43 \\
Dextronized corn starch & 14.50 \\
Sucrose & 9.00 \\
Cellulose & 5.00 \\
AIN-93 mineral mix & 3.50 \\
AIN-93 vitamin mix & 1.00 \\
1-cystine & 0.18 \\
Choline bitartrate & 0.25 \\
TBHQ & 0.10 \\
Vitamin E $\mathrm{CO}^{b}, \mathrm{FO}^{c}, \mathrm{CLA}^{d}$, FO+CLA $^{e}$ & 10.00 \\
\hline
\end{tabular}

\footnotetext{
${ }^{a}$ All diet ingredients were purchased from MP Biomedicals (Irvine, CA). CLA from Lipid Nutrition, Channahon, IL, USA and Fish oil $(($ eicosapentaenoic acid $($ EPA $) /$ docosahexaenoic acid $($ DHA $)=30 / 20))$ from Ocean Nutrition, Canada.

${ }^{b}$ Diets consisted of $10 \% \mathrm{CO}$ or $5 \% \mathrm{CO}$ with $5 \% \mathrm{FO}$ or $0.5 \%$ CLA 9.5 in CO or $0.5 \%$ CLA in $4.5 \%$ CO with $5 \%$ FO respectively.

${ }^{c}$ Diets consisted of $10 \%$ CO or 5\% CO with 5\% FO or 0.5\% CLA 9.5 in CO or 0.5 \% CLA in $4.5 \%$ CO with 5\% FO respectively.

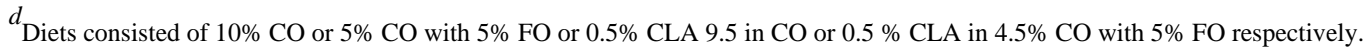

${ }^{e}$ Diets consisted of $10 \% \mathrm{CO}$ or $5 \% \mathrm{CO}$ with $5 \% \mathrm{FO}$ or $0.5 \%$ CLA 9.5 in CO or $0.5 \%$ CLA in $4.5 \%$ CO with 5\% FO respectively.
} 
Table 2

Serum metabolites and cytokines in C57Bl/6J mice fed CO, FO, CLA and CLA+FO for six months.

\begin{tabular}{|l|c|c|c|c|}
\hline Serum metabolites & & & & \\
Parameter & CO & FO & CLA & CLA + FO \\
\hline Triglycerides (mg/dl) & $70.28 \pm 2.15^{\mathrm{a}}$ & $40.66 \pm 2.42^{\mathrm{b}}$ & $45.33 \pm 6.12^{\mathrm{b}}$ & $41.21 \pm 3.05^{\mathrm{b}}$ \\
\hline NEFA (mEq/L) & $1.24 \pm 0.06^{\mathrm{a}}$ & $0.81 \pm 0.06^{\mathrm{b}}$ & $1.04 \pm 0.03^{\mathrm{a}}$ & $0.88 \pm 0.03^{\mathrm{b}}$ \\
\hline
\end{tabular}

Serum hormones and adipocyte cytokines
\begin{tabular}{l|l|l|l|l|} 
Leptin $(\mu \mathrm{g} / \mathrm{ml})$ & $7.41 \pm 0.63^{\mathrm{a}}$ & $5.22 \pm 0.60^{\mathrm{a}}$ & $3.38 \pm 0.22^{\mathrm{b}}$ & $4.30 \pm 0.61^{\mathrm{b}}$ \\
\hline Adiponectin $(\mu \mathrm{g} / \mathrm{ml})$ & $1.93 \pm 0.06^{\mathrm{a}}$ & $2.88 \pm 0.07^{\mathrm{b}}$ & $1.16 \pm 0.04^{\mathrm{a}}$ & $2.97 \pm 0.05^{\mathrm{b}}$ \\
$\mathrm{TNF}-\alpha(\mathrm{pg} / \mathrm{ml})$ & $55.12 \pm 4.24^{\mathrm{a}}$ & $42.23 \pm 2.26^{\mathrm{a}}$ & $37.43 \pm 1.44^{\mathrm{b}}$ & $37.22 \pm 2.12^{\mathrm{b}}$ \\
$\mathrm{IL}-6(\mathrm{pg} / \mathrm{ml})$ & $120.9 \pm 6.30^{\mathrm{a}}$ & $90.0 \pm 4.13^{\mathrm{a}}$ & $93.12 \pm 7.12^{\mathrm{b}}$ & $80.25 \pm 2.36^{\mathrm{b}}$ \\
\hline
\end{tabular}

Effect of diet containing CO, FO, CLA and CLA+FO on serum metabolites and cytokines in C57Bl/6J mice fed for six months. Data are means \pm SEM, ( $\mathrm{n}=10$ mice/group). Values with different letters significantly different by one way ANOVA followed by Newman-Keuls multiple comparison post hoc test $(\mathrm{P}<0.05)$. 